\title{
EXPERIENCES OF HEALTH CARE PROVIDERS MANAGING SEXUAL ASSAULT VICTIMS IN THE EMERGENCY UNIT PART 1: BACKGROUND AND METHODOLOGY
}

Authors:

Rebecca M. Skhosana

Mmapheko D. Peu ${ }^{2}$

\begin{abstract}
Affiliations:
${ }^{1}$ Department of Health, Mpumalanga Province, South Africa
\end{abstract}

${ }^{2}$ Department of Nursing Science, University of Pretoria, South Africa

\section{Correspondence to:} Mmapheko D. Peu

e-mail:

doriccah.peu@up.ac.za

Postal address:

PO Box 667, School of Health Care Sciences, University of Pretoria, Pretoria 0001, South Africa

\section{Keywords:}

patient-carer relationship; sexual assault; victims; health care providers; emergency unit

\section{Dates:}

Received: 05 Nov. 2008 Accepted: 21 July 2009

Published: 17 Sept. 2009

How to cite this article: Skhosana, R.M. \& Peu, D.M., 2009, 'Experiences of health care providers managing sexual assault victims in the emergency unit Part 1: Background and methodology', Health SA Gesondheid 14(1), Art. \#480, 7 pages. DOI: 10.4102/hsag.v14i1.480

\section{This article is available} at: http://www.hsag.co.za

(c) 2009. The Authors. Licensee: OpenJournals Publishing. This work is licensed under the Creative Commons Attribution License.

\section{ABSTRACT}

The objective of this study was to explore and describe the experiences of health care providers managing sexual assault victims in the emergency unit of a community hospital in the Nkangala district in the Mpumalanga Province. A qualitative, phenomenological design was applied. Purposeful sampling was used to select participants from health care providers who were working in the emergency unit and had managed more than four sexual assault victims. Data were collected by means of individual interviews and analysed according to the Tesch method of data analysis by the researcher and the independent co-coder.

Main categories, subcategories and themes were identified. Participants expressed their emotions, challenges and police attitudes and behaviours as well as inconsistencies in guidelines and needs identification. It was recommended that members of the multidisciplinary team engage in community activities and that the community participate in matters pertaining to sexual assault. Government should develop clear guidelines that are applicable to rural and urban South Africa. Health care sciences should aim to train more forensic nurses. All relevant departments should work together to alleviate the complications caused by sexual assault incidents.

\section{OPSOMMING}

Die doel van hierdie studie was om die ervaringe van gesondheidsorgverskaffers wat slagoffers van seksuele aanranding in die ongevalle-eenheid van 'n gemeenskapshospitaal in die Nkangala-distrik in die provinsie van Mpumalanga hanteer, te verken en te beskryf. ' $n$ Kwalitatiewe fenomenologiese ontwerp is toegepas. Doelbewuste steekproefneming is gebruik om deelnemers te selekteer uit die groep gesondheidsorgverskaffers wat in die ongevalle-eenheid werksaam was en meer as vier slagoffers van seksuele aanranding hanteer het. Data is by wyse van individuele onderhoude ingesamel en volgens die Tesch-metode van data-analise deur die navorser en die onafhanklike medekodeerder geanaliseer.

Hoofkategorieë, subkategorieë en temas is geïdentifiseer. Deelnemers het uitdrukking gegee aan hulle emosies, uitdagings, die houding en gedrag van polisiebeamptes, teenstrydighede in riglyne en behoefte-identifikasie. Aanbevelings is dat multidissiplinêre spanlede betrokke moet wees by gemeenskapsaktiwiteite en dat die gemeenskap moet deelneem aan sake wat verband hou met seksuele aanranding. Die regering moet duidelike riglyne ontwikkel wat op landelike en stedelike Suid-Afrika van toepassing is. Gesondheidsorgwetenskappe moet daarop gerig wees om meer forensiese verpleegkundiges op te lei. Alle toepaslike departemente moet saamwerk om die komplikasies te verlig wat deur voorvalle van seksuele aanranding veroorsaak word.

\section{INTRODUCTION}

A series of changes have been implemented within the national health system of South Africa with the aim of making accessible, affordable, effective and efficient services available to the community at large. Amongst the changes introduced was the abolishment, in 1999, of the district surgeon system, which was responsible for, amongst other things, the examination of sexual assault victims. According to Christofides et al. (2005:496), the main aim of abolishing the district surgeon system was to devise a strategy to improve services and to move towards integrated care in-keeping with a primary health care approach. By abolishing the district surgeon system, the South African government intended to make forensic services available to all public health care providers, including the primary health care sector, in accordance with the emphasis placed by the Alma Ata conferences on available and accessible services to communities.

Although prior to the institution of a democratic government in South Africa, district surgeons were responsible for the examination and collection of evidence in cases of alleged sexual assault, the main focus of their job was on collecting forensic evidence rather than managing sexual assault victims. According to Kim, Martin and Denny (2003:103), the district surgeon system was fraught with difficulties and was severely criticised as providing substandard care.

With the changes that were introduced, health care providers in emergency units were set the additional task of caring for sexual assault victims. Considering the high rate of sexual assault in the country, the experiences of these health care providers while managing these cases should be of interest. The available research in health sciences on the topic of sexual assault mainly focuses on the management of the survivors of sexual assault, their access to care and reviews and improvements of sexual assault management.

Health care providers play a major role in the chain of events leading up to the prosecution of those accused of sexual assault; however, little attention is paid to health care providers' experiences of the management of sexual assault victims. Kim and Motsei in Christofides and Silo (2005:10) suggest 
that there is a need to understand the experiences of nurses as community members before promoting training as a strategy to address gender-based violence.

The South African government has identified the confrontation of violence against women, especially that related to sexual assault, as a priority. On 18 April 2002, the cabinet announced that the government would continue to endeavour to provide a comprehensive package of care to survivors of sexual assault (Department of Health, 2004:4). New guidelines were drawn up in order to guide and set minimum acceptable standards for the provision of health care to the survivors of sexual assault.

However, when comparing the sexual assault statistics of South Africa with those of other countries, it can be seen that South Africa has one of the highest rates of sexual assault cases in the world. According to Kalichman and Simbayi (2004:682), in South Africa in the year 2000, 53008 sexual assault cases were reported to the police. For every 100000 members of the population, 132 women reported sexual assault. In comparison, for the same population, the rate of reported sexual assaults in other countries was 81 in Australia, 16 in the United Kingdom (UK), 32 in the United States of America (USA) and 44 in Zimbabwe (Kalichman \& Simbayi, 2004:682). A member of the executive committee (MEC) for safety and security in the Mpumalanga Province was quoted in Sogayise (2005:1) as saying that there has been an increase in crimes such as sexual assault and domestic violence.

Despite the fact that the task of managing sexual assault victims was shifted from district surgeons to emergency units, no formal training has been provided to health care providers managing sexual assault victims. Martin (2002:107) states that medical students receive some input on the topic during their six-year undergraduate training in the form of a lecture of 55 to 120 minutes, depending on the medical school. For nursing personnel, the government has introduced a forensic nursing course.

According to Kim et al. (2003:104), the training of forensic nurses was proposed as a means of meeting the need for professionals trained to manage sexual assault cases. Professional nurses from different provinces were recruited to undergo a course in forensic nursing. However, the training of these nurses is occurring at an extremely slow pace and not all tertiary institutions offer the forensic nursing course. The first 18 forensic nurses of the Mpumalanga Province graduated in 2004. However, some of them have already left the service. The management of sexual assault victims is also largely reliant on community service doctors, who are limited in numbers, and other health care providers, who have not received formal training on the management of sexual assault victims.

After completing the forensic nursing course, the first 18 forensic nurses to be trained in the Mpumalanga Province were distributed throughout the province, but because of their small numbers, some districts were left without these valuable health care providers. In areas where there are no forensic nurses, the community service doctors manage most sexual assault survivors. According to Knight (2001:135), in many areas specialist doctors, such as police surgeons, gynaecologists or members of medical institutes, take up the task of managing the care of sexual assault survivors; elsewhere, however, the police or courts may ask any doctor to perform this task.

\section{Background to the problem}

Since September 2002, selected clinics and hospitals in South Africa have been authorised to provide antiretroviral therapy (azidothymidine [AZT] and lamivudine [3TC]) to prevent the transmission of the human immunodeficiency virus (HIV) to sexual assault victims (Collings 2005:17). The protocol restricts the post-exposure prophylaxis to those victims who test HIV negative and report to the facility within 72 hours of the assault.
However, some survivors of sexual assault are not treated according to this protocol. Those who are not ready to be tested for HIV are not given the treatment for the three days that would allow them more time to make this decision.

Some sexual assault survivors are not given the emergency contraceptive pill (ECP). For example, in May 2006, a survivor who was treated in the emergency unit received negative results for the initial pregnancy and HIV tests but when she reported for a second visit, both pregnancy and HIV tests were positive. It was later discovered that she had received the postexposure prophylaxis from the service provider 48 hours after the examination. According to Smuger in Goldenring and Alfred (2001:1169), the issue of improper post-exposure care rendered in hospital emergency rooms has existed for many years and is still a problem.

Furthermore, some health care providers are not familiar with the procedures related to sexual assault management. This is a problem for both the health care service provider and the survivor. Without familiarity with the contents of the sexual assault evidence collection kit, evidence cannot be collected properly. It has been noted that for every 394 women that are raped, only one perpetrator is successfully convicted (Brouwer 2005:837). According to the South African Police Service (SAPS) Mpumalanga annual report (SAPS 2003/2004:42), the disposal rate of sexual assaults cases was $62.61 \%$ during the $2003 / 2004$ period - a very high percentage. One of the reasons given for the low prosecution rate was poor collection of biological evidence from the survivor.

In the Nkangala district, it was discovered that with the exception of forensic nurses who have undergone a full one-year training course, health care service providers had been subjected to only 45 to 60 minutes of training, provided by a family medicine specialist, on the subject of the management of sexual assault cases. According to Du Mont and Parris (2004:517), there was no standard training for sexual assault physicians. Martin (2002:110) states that even the former district surgeons acquired their skills through observation, teaching one another, self-study and reading, and being interested in the well-being of sexual assault survivors.

Another problem arising from the management of sexual assault cases in the emergency unit is the increased workload of the remaining health care providers working in the unit when a health care provider is called to appear as a witness in court. In addition to this, a health care provider who appears in court as a witness faces an entirely different situation than when rendering medical care. Providing courtroom testimony can be uncomfortable, unpredictable and, because of frequent delays, time-consuming, and therefore can interfere significantly with clinical practice (Ledray \& Barry 1998:284). According to Ledray and Barry (1998:288), medical professionals have avoided becoming involved in sexual assault cases because of the risk that they may have to testify in court.

Martin (2002:109) argues that sexual assault survivors and the South African Department of Justice expect the medical examiner to have all the necessary skills and training to document and interpret injuries and collect medical evidence. A perceived lack of concern and insensitivity can demoralise the survivor during this sensitive stage of his/her rehabilitation (Odentaal, Schaetzing \& Kruger 2001:224).

Based on the above background, the researcher thought it necessary to conduct an investigation into the experiences of health care providers managing sexual assault victims in an emergency unit.

\section{PROBLEM STATEMENT}

The researcher found that the management of victims of sexual assault in one Nkangala district community hospital in the 
Mpumalanga Province had become a problem. This was based on the fact that health care providers were reluctant to render a service to sexual assault victims. Sexual assault survivors often had to wait for long periods to be attended to by the health care providers. According to Odentaal et al. (2001:227), the sexual assault survivor's examination must be expeditiously completed in order to prevent loss of forensic evidence and to minimise the distress of the survivor.

Some health care providers at this hospital delegated part of the management of sexual assault survivors to other nursing staff who were not skilled in managing sexual assault cases. This included delegating tasks such as pre- and post-counselling, the taking of blood, education regarding family planning and education regarding the taking of the treatment prescribed and its side effects. In the National Management Guidelines for Sexual Assault Care (Department of Health 2004:11), it is stated that continuity of care contributes to building trust and a sense of safety for the survivor. In this hospital, it was noted that sexual assault survivors were exposed to several different health care providers during their management in the unit. For example, one nurse took the survivor's vital signs, another nurse took the survivor's history, a social worker conducted pre-counselling and a third nurse took blood. The above procedure also irritated the nurses because it was time consuming.

\section{Significance of the study}

The findings of the study can assist in uncovering the root cause of the problems in the management of sexual assault victims and thereby improve the management of sexual assault victims to meet the set minimum standard of care. The study highlights the need to train more forensic nurses and identifies the lack of training of other health care providers (such as medical doctors) as well as reviews and replans their training in the area of the management of sexual assault victims.

The study can also assist in minimising legal abortions and the spread of HIV contracted through sexual assault through encouraging the treatment of sexual assault victims as per protocol. The investigation reinforces the importance of managing sexual assault victims comprehensively (holistically).

\section{Research question}

Burns and Grove (2003:387) define a research question as a concise interrogative statement that is worded in the present tense and includes one or more variables or concepts. The research question for this study was, 'What are your experiences with regard to the management of sexual assault survivors in your emergency unit?'

\section{Purpose of the study}

The purpose of this study was to investigate the experiences of health care providers managing sexual assault victims in the emergency unit of a selected hospital in the Nkangala district in the Mpumalanga Province.

\section{Objective of the study}

The objective of this investigation was to explore and describe the experiences of health care providers managing sexual assault victims in the emergency unit.

\section{DEFINITION OF CONCEPTS}

\section{Experiences}

In this study, experiences are defined as what is happening in the life of an individual, the importance of what is happening and the changes that can be made. In other words, experiences are what is happening or has happened in the physical, psychological and social life of an individual.

\section{Health care providers}

According to the Department of Health (2004:139), the term health care provider for sexual assault survivors refers to a medical officer, specialist or nurse who should have received the appropriate and necessary training.

\section{Sexual assault}

In the National Management Guidelines for Sexual Assault Care (Department of Health 2004:139), sexual assault refers to circumstances in which there is forced penetration to any extent whatsoever by the genital organs of one person, or by any object, including any part of the body of an animal or any part of the body of a person, into the anus, mouth and/or genital organs of another person.

\section{Victims}

Victims are survivors who have experienced multiple forms of abuse, including past and present physical abuse, emotional abuse, rape, and so forth.

\section{Emergency unit}

An emergency unit is a department of an institution in which medical conditions that require immediate treatment are treated (Tulloch 1993:479).

\section{Management}

For the purposes of this study, management is defined as care rendered by health care providers to sexual assault victims as per the National Management Guidelines for Sexual Assault Care (Department of Health 2004), that is to say, holistic care.

\section{ETHICAL CONSIDERATIONS}

The following primary ethical principles on which the standard of ethical conduct in research is based were adhered to in this study: the principle of beneficence, the principle of human respect and dignity and the principle of justice.

In order to ensure that the participants were protected from harm, the researcher informed them of their rights to terminate their participation in the study at any time they deemed it necessary. The researcher ensured that the participants were free from exploitation by not taking advantage of the situation to her own benefit. Another dimension of the principle of beneficence that was looked at was the risk/benefit ratio. The participants were informed about the significance of the study to the profession and the community at large.

As prescribed by De Vos, Strydom, Fouché and Delport (2002:65), the participants were informed of the goal of the investigation, the possible advantages, disadvantages and dangers to which they could have been exposed, and of the credibility of the researcher.

Permission to conduct the investigation was obtained from the Research Committee of the Mpumalanga Province, from the Ethics Committee of the Faculty of Health Science at the University of Pretoria and from the management of the hospital where the study was conducted.

The principle of justice includes the right to fair treatment and the right to privacy (Polit, Beck \& Hungler 2001:81). The participants' right to privacy in the study was respected. The researcher arranged an information session with all the participants prior to the initial interview to allow them to choose the time most suitable for them. The researcher did not attach the names of the participants to the transcripts. In doing so, the researcher ensured the confidentiality of the participants.

In order to protect their right to fairness, the researcher ensured that all participants were treated equally. For example, those who needed debriefing were informed where they could access that service. The contact numbers of the psychologist who offered free consultation were included in the consent form. 
The researcher avoided taking advantage of the situation by all means possible. The researcher observed and paid attention to the things that caused discomfort and unease to the participants in the course of the study.

Subjectivity and collaboration made the researcher vulnerable. Being emotionally immersed in the lived experience of others requires an inner strength that can be enhanced by selfcare (Streubert \& Carpenter 2003:319). The researcher used debriefing to explore her personal responses and weigh the risk/ benefit ratio of the study. The researcher implemented personal education and consulted with an expert whenever she believed there was a risk related to emotions of participants.

\section{RESEARCH METHOD}

Due to the nature of the study, the researcher conducted the study in a qualitative paradigm. The phenomenological approach was used to uncover the experiences of health care providers managing sexual assault survivors in an emergency unit.

\section{Research population and sampling}

The population of this study consisted of the health care providers of Mpumalanga Province. However, Mpumalanga Province is a very large area. The researcher had to identify a more accessible population. The accessible population consisted of the health care providers of the Nkangala district in Mpumalanga Province.

The researcher conducted purposeful sampling to select the participants of the study, as the investigation was conducted according to the phenomenological approach. Maximum variation sampling was used. For the study, the researcher purposefully selected health care providers from a group of professional nurses and medical doctors.

The sample of this study was composed of nine health care providers working in the emergency unit of the selected hospital in the Nkangala district in the Mpumalanga Province. The researcher started by interviewing those participants with more experience in the service and in the institution, because they could provide more information. Those participants with less experience in the service and the institution were interviewed later. The sample of the study was made up of five professional nurses and four medical doctors. Three of the professional nurses were female and two were male. Three of the medical officers were male and one was female. The ages of the participants ranged from 26 to 45 years old. The work experience of the participants ranged from two to 15 years. The experiences of those who were older and more experienced differed from those who were younger and had less experience in managing sexual assault survivors.

The inclusion criteria for the study were as follows: The participants of the study had to work in the emergency room of the selected hospital. Participants should have managed more than four sexual assault victims in the emergency room of the selected hospital. All participants were to be able to speak English as the study was conducted in English. Participants who did not work in the emergency room of the selected hospital were excluded. Participants who had managed more than four sexual assault victims in other institutions but not in the selected hospital were also excluded. All nine participants were Africans who met all the criteria for inclusion in the study. There was no age or race restriction for the sample.

\section{Data collection methods}

In this study, the researcher used in-depth interviews, observations and field notes to collect data from the individual participants. According to Struwig and Stead (2004:240), an interview is a method of gathering data by asking people questions. Polit et al. (2001:282) note that observations are usually supplemented with the information gained from unstructured interviews. The researcher used field notes to document the unstructured observational data collected during the interviews. Polit et al. (2001:282) describe field notes as daily records of events and conversations in a much broader, more analytical and more interpretative way. The researcher categorised the field notes for the study according to their purpose. The researcher took observational notes during all the interviews with the participants. Observational notes are records of information, such as the time and place that the conversations occurred as well as the activities that took place during the conversations that were recorded.

The researcher attempted to attach meaning to observations made during the interviews by taking theoretical notes. Personal notes were also taken during the interviews. Personal notes are concerned with the researcher's feelings and comments about the process of the study. The researcher took methodological notes during the interviews in order to guide subsequent observations.

The pilot study was conducted in order to ensure that the research question was not ambiguous and to test the interviewing skills of the researcher. Participants for the pilot study were purposefully selected and consisted of two female professional nurses and one male medical officer. Two female participants were chosen because there were more female than male health care providers working at the institution where the study was conducted. The interviews for the pilot study were conducted during working hours or after hours, depending on the busyness of the unit. Because of the sensitive nature of the topic, the researcher interviewed participants of the pilot study face to face, individually. According to Rossouw (2003:146), the researcher must make an appointment to meet the participants at the venue that is most convenient and comfortable for them and ensure that the venue is free from distractions. Consent to conduct the pilot study in the unit and permission to use her office for the interviews were obtained from the unit manager.

During the pilot study, the broad research question 'What are your experiences with regard to the management of sexual assault survivors in your emergency unit?' was asked. The researcher recorded the interviews conducted with the participants during the pilot study on audiotape with their permission. An experienced medical officer in the institution listened to the tapes of the interviews in order to identify problems and provide guidance where necessary. Minor problems with regard to the researcher's interviewing skills were identified and corrected.

The researcher began conducting the initial interviews a week after the pilot study. Potential participants in the study were contacted individually by the researcher prior to the interview and requested to participate in the study. Participants verbally agreed to participate in the study. Later, the researcher gave participants the information leaflet and the consent document to sign. In the information leaflet, the purpose of the study, the nature of the study, procedures to be followed during the study and issues regarding freedom of choice to participate in the study were discussed and the contact numbers of the person who would offer free counselling were provided. Participants preferred to have the interview after hours, after 16:00 when the emergency unit was no longer busy. Appointments were secured with each participant.

Professional nurses on day duty were interviewed individually after 16:00, while they were still on duty. Those who were on night duty were also interviewed while they were on duty. Medical officers were interviewed while they were on call in the unit, also after 16:00. The researcher spent 45 to 60 minutes with each participant. The data were recorded on audiotape. Later in the evening, the researcher would transcribe the data collected on that particular day. Because of the times set by the participants for the interviews, the researcher took a month to collect the data. During the interviews, the researcher used the following communication skills: paraphrasing, validating, reflection, focusing and listening, and probing. 


\section{Data analysis}

The data were analysed using Tesch's (1990) method of qualitative data analysis. Clarke and Cresswell in Lehana and Rhyn (2003:29) state that this method entails scrutinising the data obtained for the emergence of themes. Through Tesch's method of data analysis, the researcher aimed to capture the essence of the experiences studied through the identification of their constituent parts.

The researcher started by transcribing the data from the audiotapes. The transcripts were read carefully in their entirety and compared to the tapes for accuracy. Some ideas were jotted down as they came to mind. The transcripts were arranged in such a way that those that were interesting and short were placed on top of the pile. The researcher then chose one transcript at a time and reviewed it. During the review of each transcript, the researcher asked questions that shed light on the underlying meanings.

A list of topics was made for each transcript. These topics were then clustered according to similarity. The list of topics was compared to the data and codes were allocated to each topic. The most descriptive wording for each topic was found and this wording became the categories of the data. The data were then divided up and organised into the relevant categories. Participants were given the opportunity to clarify the researcher's interpretations of the data both during and after the interviews. The tapes and the transcripts were also given to a professional experienced in the examination of sexual assault victims for inquiry audit.

\section{TRUSTWORTHINESS OF THE FINDINGS}

According to Polit et al. (2001:312), there are four criteria that must be met to establish the trustworthiness of qualitative data. The researcher used these criteria to ensure trustworthiness. These criteria are credibility, transferability, dependability and confirmability.

\section{Credibility}

Polit et al. (2001:12) define credibility as confidence in the truth of the data. Terre Blanche and Durrheim (1999:56) note that credible research produces findings that are convincing and believable. In order to produce findings that are convincing and believable, the researcher implemented the following strategies: prolonged engagement, persistent observations, peer debriefing, member check and triangulation.

\section{Prolonged engagement}

According to Polit et al. (2001:313), prolonged engagement is the investment of sufficient time in data collection activities to gain an in-depth understanding of the culture, the language or the views of the group under study and to test for misinformation. The researcher spent sufficient time on data collection activities. This included time spent with the participants during the preparation phase, the pilot study and the interview sessions. The researcher also spent time transcribing the data from the audiotape and analysing the data according to Tesch's method of data analysis.

\section{Persistent observations}

Polit et al. (2001:313) define persistent observations as the researcher's focus on the aspects of the situation that are relevant to the phenomenon being studied. During the study, the researcher continuously observed the language of the participants, changes in their voices as well as their gestures and facial expressions. For example, the participants often referred to the sexual assault incident as 'that thing' instead of using the term rape or sexual assault.

\section{Peer debriefing}

Streubert and Carpenter (2003:265) define peer debriefing as a process that enables the researcher to articulate and reflect on research with a colleague or informed associate. Polit et al. (2001:314) state that peer debriefing exposes the investigator to the searching questions of others who are experienced in either qualitative research or in the phenomenon being studied or both. For this study, the researcher conducted peer debriefing with a forensic nurse from a different institution in order to review and explore some of the aspects of the investigation. One aspect that was discussed with this nurse was the scheduled working hours of the institution at which she worked, because the forensic nurse at the institution where the study was conducted reportedly worked office hours while most sexual assault victims reported to the emergency unit during the night or holidays. The emotional aspect of the study was also reviewed. The researcher wanted to ascertain whether this forensic nurse had had similar experiences to those of the rest of the participants.

\section{Member check}

Member checking refers to providing feedback to the participants regarding preliminary findings and interpretations and determining the participants' reactions (Polit et al. 2001:314). During the study, the researcher conducted member checks both in an informal and a formal manner. During the data collection session, the researcher paraphrased and validated what the participants said, for example by asking questions such as 'If I understood you correctly, you said it is very difficult to manage sexual assault survivors?' The researcher formally conducted a member check by giving each participant the script of the transcribed data so that participants could confirm that what had been written in the transcripts was what they had said.

\section{Triangulation}

Polit et al. (2001:314) state that triangulation is the use of multiple references to draw conclusions about what constitutes the truth. For this study, the researcher used the method of triangulation in which data is collected in different forms, such as interviews, observations and tapes. The data was analysed by the researcher and a professional experienced in qualitative research. This kind of triangulation is referred to as investigators' triangulation. Theory triangulation is the use of multiple perspectives to interpret a set of data (Polit et al. 2001:314). The researcher took theoretical notes during the data collection sessions. Through triangulation, the researcher strove to differentiate the true information from the information containing errors.

Struwig and Stead (2004:145) state that different sources of data can be employed. In this study, the sample was composed of health care providers from two disciplines, nursing and medicine. The researcher noticed that these two groups of health care providers sometimes gave conflicting information. For example, the nurses stated that sexual assault survivors had to wait for long periods of time before being seen to, while the medical officers said that survivors were given priority when they arrived. This is not supported by the participants' concern with the attitudes of police officers regarding the duration of time spent at the hospital when accompanying sexual assault survivors.

\section{Transferability}

Babbie and Mouton (2001:277) refer to transferability as the extent to which findings can be applied in other contexts or to other participants. Brink (2002:124) describes transferability as the degree to which the results of the study can be generalised to a setting or sample other than the one studied. During this study, the researcher ensured transferability by the following means: purposeful sampling and thick description.

\section{Purposeful sampling}

Purposeful sampling occurs when the researcher intentionally selects participants who have experience with the phenomenon or the key concept being explored (Cresswell \& Plano Clarke 
2007:112). In this study, the researcher intentionally selected participants from both medical and nursing disciplines who had worked in the emergency unit and had managed more than four cases of sexual assault. These participants were able to provide information about what they had experienced during the management of sexual assault survivors. For example, most of the participants were concerned about heavy workloads, the link between alcohol and sexual assault, the fact that most cases occurred at night, and other such issues. Participants had experience of what they were discussing.

\section{Thick description}

According to Streubert and Carpenter (2003:225), transferability is established by thick description, which, when read by another researcher, can enable the findings of the research to be applied in another context. Stringer in Streubert and Carpenter $(2003: 225)$ indicates that it is the researcher's responsibility to describe as fully as possible the means for applying the information in another context. During the study, the researcher used interviews, observational and theoretical notes as well as audiotape recordings, which, when they were combined during the data analysis, contained enough information to permit judgement about contextual similarities. Furthermore, a literature control was conducted in order to contribute to thick description.

\section{Dependability}

According to Terre Blanche and Durrheim (1999:64), dependability refers to the degree to which the reader can be convinced that the findings were indeed what the researcher claims. Streubert and Carpenter (2003:265) state that it is the researcher's responsibility to provide enough information to allow another researcher reading the study to come to similar conclusions. The researcher used the following approaches to ensure that the findings of this study were stable over time and conditions: stepwise replication, inquiry audit and approaches used to ensure credibility.

\section{Stepwise replication}

Polit et al. (2001:317) describe stepwise replication as an approach similar to the split-half technique. It involves dividing several researchers into two teams to deal with the data separately. In this study, the data were analysed separately by the researcher and a professional experienced in qualitative research. The findings of the researcher were then compared to those of the experienced professional.

\section{Inquiry audit}

An inquiry audit involves the scrutinising of the data and supporting documents by an external reviewer (Polit et al. 2001:314). In this study, an inquiry audit was conducted by requesting the unit manager and medical manager to read the transcripts of all the interviews. Each one constructed independent interpretative summaries of the interviews, which were compared to the findings. For example, both agreed that the interviews highlighted the need for more people to be trained in the management of sexual assault cases.

\section{Approaches used to ensure credibility}

According to Guba and Lincoln in Babbie and Mouton (2001:277), Polit et al. (2001:315) and Streubert and Carpenter (2003:225), there is no credibility without dependability. Therefore, the strategies used to ensure credibility also ensured dependability. The strategies used to ensure credibility were peer debriefing, member check, prolonged engagement, triangulation and persistent observations.

\section{Confirmability}

Confirmability is the guarantee that the findings, conclusions and recommendations of the study are supported by the data and that there is an internal agreement between the researcher's audit procedures (Brink 2002:125). Confirmability is the degree to which the findings are the product of the focus of the inquiry and not the biases of the researcher (Babbie \& Mouton 2001:279). However, Sandelowski in Streubert and Carpenter (2003:39) argues that only the researcher who has collected the data and been immersed in them can confirm the findings. The researcher used the following strategies to ensure the confirmability of the study: researcher as the research tool and pilot study.

\section{Researcher as the research tool}

During the interviews, the researcher was able to bracket any preconceived ideas about the topic. For example, the notion that female sexual assault victims feel more at ease when being treated by a female practitioner was suspended and both male and female participants were included in the study.

\section{Pilot study}

A pilot study was conducted to test the research question. The researcher's mentor confirmed that the research question would yield good results.

\section{CONCLUSION}

The researcher conducted the study within a qualitative paradigm. The chosen design for the study was phenomenological. The researcher decided to follow this design because the investigation was based on the experiences of health care providers managing sexual assault victims in the emergency unit. Other researchers have discovered that little research has been conducted into the experiences of health care providers, especially when it comes to sexual assault issues. Despite the fact that health care providers deal with sexual assault victims almost daily, very few researchers have investigated the experiences that health care providers undergo while doing this sensitive work.

\section{REFERENCES}

Babbie, M. \& Mouton, J., 2001, The practice of social research, Oxford, Cape Town.

Brink, N., 2002, Fundamentals of research methodology for health care professionals, Juta, Cape Town.

Brouwer, I.J., 2005, 'Training and development needs of medical practitioners involved in the medico-legal examination of survivors of sexual assault', South African Medical Journal 99(11), 837-838.

Burns, N. \& Grove, S.K., 2003, Understanding nursing research, 3rd edn., WB Saunders, Philadelphia.

Christofides, N.J., Jewkes, R.K., Webster, N., Penn-Kekana, L., Abrahams, N. \& Martin, L.J., 2005, 'Other patients are really in need of medical attention: The quality of health services for rape survivors in South Africa', Bulletin of the World Health Organisation 83(7), 495-501.

Christofides, N.J. \& Silo, Z., 2005, 'How nurses' experiences of domestic violence influence service provision', Nursing and Health Science 7, 9-14.

Collings, S.J., 2005, 'Provision of antiretroviral prophylaxis to child rape victims in South Africa: HIV status and deployed reporting', Psychological Reports 97, 17-18.

Cresswell, J.W. \& Plano Clark, V.L., 2007, Designing and conducting mixed methods research, Sage, London.

Department of Health, 2004, National management guidelines for sexual assault care, Government Printers, Pretoria.

De Vos, A.S., Strydom, H., Fouché, H. \& Delport, C.S.L., 2002, Research at grass roots for the social sciences and human service professions, 2nd edn., Van Schaik, Pretoria.

Du Mont, J. \& Parris, D., 2004, 'The doctor's dilemma: Care giving and medico-legal evidence collection', Journal of Medicine and Law 23, 515-529.

Goldenring, J. \& Alfred, G., 2001, 'Post-rape care in hospital emergency rooms', American Journal of Public Health 36(3), $1169-1170$ 
Kalichman, S.C. \& Simbayi, L.C., 2004, 'Sexual assault history and risk for sexually transmitted infections among women in an African township in Cape Town, South Africa', Aids Care 16(6), 681-689.

Kim, J., Martin, L.J. \& Denny, L., 2003, 'Rape and HIV postexposure prophylaxis: Addressing the dual epidemics in South Africa', Reproductive Health Matters 11(22), 101-112.

Knight, B., 2001, Simpson's forensic medicine, 11th edn., Oxford, London.

Ledray, L.E. \& Barry, L., 1998, 'Sexual assault clinical issues: SANE expert and factual testimony', Journal of Emergency Nursing 24(3), 284-289.

Lehana, T.V. \& Rhyn, L., 2003, ‘Phenomenological investigation of experiences of pregnancy by unmarried adolescents in Maseru', Health SA Gesondheid 18(1), 26-37.

Martin, L.J., 2002, 'Forensic evidence collection: South African perspective', International Journal of Gynaecology and Obstetrics 78 (suppl. 1), 105-110.

Odentaal, H.I., Schaetzing, A.E. \& Kruger, T.F., 2001, Clinical gynaecology, 2nd edn., Juta, Pretoria.
Polit, D.F., Beck, C.T. \& Hungler, B.P., 2001, Essentials of nursing research: Methods appraisal and utilization, Lippincott, Philadelphia.

Sogayise, N., 2005, 'Domestic violence', Ukuphephakwethu: Official newsletter of the Mpumalanga Department of Safety and Security.

South African Police Service, 2003/2004, 'Annual report (Mpumalanga)', SAPS, Pretoria.

Streubert, H.J. \& Carpenter, D.R., 2003, Qualitative research in nursing: Advancing the humanistic imperative, 3rd edn., Lippincott, Philadelphia.

Struwig, F.W. \& Stead, G.B., 2004, Planning, designing and reporting research, Pearson Education, Cape Town.

Terre Blanche, M. \& Durrheim, K., 1999, Research in practice: Applied methods for social science, University of Cape Town Press, Cape Town.

Tesch, R., 1990, Qualitative research: Analysis of types and software, The Falmer Press, New York.

Tulloch, S., 1993, The Reader's Digest: Oxford complete word finder, The Reader's Digest Association, London. 